Bull. Fac. Agric., Cairo Univ., 58 (2007):188-197.

\title{
MOLECULAR APPROACH TOWARDS UNDERSTANDING THE BASIS OF POTATO RESISTANCE TO Phytophthora infestans
}

(Received: 15.11.2006)

\author{
By \\ G.M. G. Shehab, O.K. Ahmed, O.M. Elshihy*and M .A. M. Ahmed ** \\ Agricultural Biochemistry Department, * Agricultural Botany Department \\ **Plant Pathology Department, Faculty of Agriculture, Cairo University, Giza, Egypt
}

\begin{abstract}
The identification of a large number of genes expressed during the interaction between potato and the causal agent of the late blight disease, Phytophthora infestans, particularly leading to the establishment of resistance, will contribute greatly to the understanding of the molecular basis of resistance.

Six different potato cultivars (Atlantic, Desiree, Goldrush, Nicola, Sante, and Spunta) were tested for their resistance to infection with a virulent isolate of $P$. infestans. This virulent isolate was selected from 10 isolates collected from diseased fields in Gharbia, Beheira and Kafr Elshaikh Governorates, Egypt. The results indicated that cv. Spunta is considered as the resistant cultivar; cv. Sante and cv. Nicola were moderately resistant; cv. Desiree and cv. Atlantic were moderately susceptible, while cv. Goldrush was highly susceptible. The suppression subtractive hybridisation ( $\mathrm{SSH}$ ) method was employed to construct a cDNA library rich in the differentially expressed sequences that are induced during the compatible interaction between potato cultivar Spunta and virulence isolate of $P$. infestans. After screening of the cDNA clones with the forward subtracted probe using inverse northern analysis, several differentially expressed cDNA clones were detected. Of the 139 clones that were detectable by this method, thirty cDNAs were sequenced. The majority of the sequenced cDNAs had very strong homologies to sequence entries in the databases. These sequences were assigned to four main functional groups, according to their putative function. These categories included: defence and stress, signalling, metabolism and unknown function.
\end{abstract}

Key words: cDNA library, gene expression, late blight, Phytophthora infestans, Potato, resistance, suppression subtractive hybridisation, screening.

\section{INTRODUCTION}

The oomycete Phytophthora infestans, the causal pathogen of the late blight disease of potato and tomato is reckoned to be the most damaging microbial pest of potato crops worldwide. Also, it is one of the major problems in the potato industry since this devastating pathogen attacks both tuber and foliage during all stages of crop development and causes severe losses in potato fields every year. Annual losses due to the late blight and measures for its control are estimated to exceed five billion dollars worldwide (Duncan, 1999).

Late blight is controlled by the application of fungicides. The disadvantage of protection by chemicals is that the quantities used and frequencies of application, in practice, are often higher than necessary. This means financial and environmental consequences, and more importantly it leads to the evolution of resistance and more virulent fungal isolates. Because of the recent spread of more virulent forms of $P$. infestans and the economic importance of potato, as the fourth most important food crop worldwide after wheat, maize, and rice, development of resistance to this pathogen is currently badly needed and one of the highest objectives in potato breeding programs (Ewing et al., 2000; and Gebhardt and Valkonen, 2001).

Traditionally, genetic resistance of potato against late blight is classified into two different types: the race-specific and race-nonspecific resistance. Race-specific resistance is mediated by $R$ genes that lead to a race-specific hypersensitive response. Generally speaking, these $\mathrm{R}$ genes only provide short-lived resistance in the field as new virulent races of the pathogen rapidly overcome the resistance encoded by single race-specific resistance 
genes (Fry and Goodwin, 1997). In contrast, racenonspecific resistance is controlled by many interacting genes that do not prevent infection, but slow down the development of the pathogen at individual infection sites on the plant, and hence, lasts longer (Colon et al.,1995; and Vleeshouwers et al., 2000).

In spite of concerted research on the genetics and physiology of $P$. infestans and its interaction with potato, progress in understanding the molecular processes involved in infection and resistance is still limited. Several studies have demonstrated that the potato attack by $P$. infestans leads to transcriptional activation of various genes in potato (Avrova et al., 1999; Beyer et al., 2001; Birch et al., 1999; Wang et al., 2005; and Zhu et al., 1995). Unfortunately, the most commonly studied type of resistance, in the P.infestans-potato interaction, is race-specific resistance.

Although, race-nonspecific resistance is believed to be effective against all known races of $P$. infestans and provides in addition some level of general resistance, until now the genetic bases of this type of resistance is still unknown and the molecular mechanisms are poorly understood. The identification and characterisation of these genes might lead to a better understanding of the molecular processes involved in resistance, as well as potentially contributing to the development of biotechnological strategies for the fight against this disease.

In the present study, a subtracted cDNA library enriched for low abundance differentially expressed sequences that are induced during the compatible interaction between potato plants and $P$. infestans was constructed using the suppression subtractive hybridisation (SSH) technique (Diatchenko et al., 1996). Novel potato gene sequences that had not been shown to be induced by pathogens before were identified, as well as a number of gene sequences that were previously shown to be activated during stress and resistance responses.

\section{MATERIALS AND METHODS}

This paper presents a piece of work, which has been done in Egypt during 2004-2006 and was supported partially from Cairo University (projects for young researchers).

All general chemicals were obtained from Sigma - Aldrich Company Ltd, Poole, Dorest, UK and were of analytical grade. All fine chemical, unless otherwise stated, were obtained from Promega Corporation. PCR - select $^{\mathrm{TM}}$ cDNA Subtraction Kit (K 1804-1) and Advantage 2 Polymerase Mix (8430-1) were purchased from Clontech Laboratories UK Ltd. TOPO ${ }^{\mathrm{TM}}$ TA Cloning kit (45-0640) was from Invitrogen. GeneRuler $1 \mathrm{~Kb}$ DNA ladder (SM0311) was purchased from MBI Fermentas. PCR DIG probe synthesis kit (1636090) was from Roche Diagnostics.

Phytophthora infestans was isolated from diseased specimens collected from diseased fields in Gharbia, Beheira and Kafr Elshaikh Governorates, North Egypt. Some of the isolated $P$. infestans strains showed evidence of contamination, so the purification was achieved by direct inoculation of the pathogen onto a potato leaf and plating the diseased leaf onto $P$. infestans selective media. The purified isolates (10 isolates) were tested for pathogenicity using a zoospore suspension and a susceptible cultivar (Shepody). The highest virulent one (isolate 4) was selected for susceptibility test.

Potato tubers cultivars Atlantic, Desiree, Goldrush, Nicola, Sante, Shepody, and Spunta were obtained from the Agricultural Research Center, Ministry of Agriculture, Giza, Egypt.

\subsection{Inocula preparation}

For pathogenicity test, inocula were prepared as a zoospore suspension. Sporangia were scrapped from the surface of well-grown cultures using a flamed thin glass rod and immediately transferred to a small dish ( $5 \mathrm{~cm}$ in diameter) containing $2 \mathrm{ml}$ of sterile water. Dishes were incubated at $8-10^{\circ} \mathrm{C}$ for 3 hours for zoospore liberation. Suspensions were usually examined under microscope to confirm zoospore liberation.

For susceptibility test, inocula were prepared as mycelium plugs. Mycelium plugs were prepared from actively growing fungal cultures, excised when the size of the colony reached about half of the diameter of the Petri dish ( 2 weeks). A sterile cork borer of $5 \mathrm{~mm}$ diameter was used to excise a plug at the advancing edges of the fungal colony. Each plug was assumed to contain mycelium of approximately the same age.

\subsection{Initiation, Propagation and Maintenance of Potato tissue culture plantlets}

The different potato (Atlantic, Desiree, Goldrush, Nicola, Sante, Shepody, and Spunta) plants were initiated from tuber in pots containing a sterile mixture of the soil: vermiculite $(2: 1 \mathrm{v} / \mathrm{v})$. 
After 4 weeks the nodes were used to initiate the tissue culture plantlets after surface- sterilization by gently shaking in $70 \%(\mathrm{v} / \mathrm{v})$ ethanol followed by Clorox 20\% (v/v) containing 1-2 drops of Tween 80. The jars were placed in a tissue culture growth room at $23-25^{\circ} \mathrm{C}$ under a regime of $16 \mathrm{~h}$ light and $8 \mathrm{~h}$ dark. Newly developed shoots were excised and transferred onto fresh MS-medium to develop a potato plantlet. Plantlets were propagated and maintained using nodal cuttings every 4-6 weeks (Shehab, 2002).

\subsection{Pathogenicity test and selection of virulent isolates}

Ten virulent isolates were tested for pathogenicity and detached leaves from Shepody tissue culture plants (susceptible to late blight) were used. The leaf-bridge bioassay method, was used to test the pathogenicity and selection of the virulent isolates (Shehab, 2002). Briefly, three-compartment Petri dishes were used in which MS-medium was placed in one compartment of each Petri dish. Two detached leaves from the same position on the plants, and of approximately the same size and appearance were immersed in the medium and the leaf tip laid over the dividing wall into the adjacent empty compartment. The partition between compartments supported the leaf "leaf-bridge" keeping it off the surface of the agar thus preventing liquid flow by capillary action. The leaves were elicited by applying $10 \mu \mathrm{l}$ of a dense zoospore suspension on the centre of each leaflet and allowing the liquid to infiltrate the leaf tissues. The infiltrated leaves together with appropriate controls (infiltrated with sterile distilled water) were incubated at $18-20^{\circ} \mathrm{C}$ for 8 days, and the average diameter of the necrosed area was daily recorded. Production of sporangia was checked under the microscope. Two of the ten tested isolates were more virulent (isolates 4 and 6), while the others varied from low to moderate virulence. Isolate 4 the highest virulent one - was selected for susceptibility test.

\subsection{Susceptibility test of potato cultivars to infection with $P$. infestans}

Screening of susceptibility of different potato cultivars was carried out using actively growing mycelium plugs. Four-week old plants were chosen to be approximately the same size and appearance. Plants were challenged by placing a disk of the pathogen mycelium plug (5mm diameter) adjacent to the plant stem. The jars were then sealed with parafilm and the plants were incubated under the same environmental conditions described above.

\subsection{Exposure of potato plants to $P$. infestans}

The four-week old plants chosen were challenged by placing a disk of the pathogen mycelium plug ( $5 \mathrm{~mm}$ diameter) adjacent to the plant stem. Two independent groups (eight - ten plants each) were used for each experiment. Treated and untreated samples from each group were collected at different time intervals $(0,4,7,15$ and 30 days post challenge), starting from leaf number four going upwards.

\subsection{Isolation of RNAs}

Total RNA from frozen potato leaf tissues collected at different time points as well as from the pathogen, was isolated using TRIR reagent ( $A B$ gene) according to the single-step RNA isolation developed by Chomczynski and Sacchi (1987). Purification of mRNA was performed using a Dynabeads mRNA purification Kit by following the manufacturer instructions. The purity of RNA preparations was checked by absorbance at $260 \mathrm{~nm}$ and $280 \mathrm{~nm}$ and the integrity was checked by electrophoresis on $0.8 \% \quad(\mathrm{w} / \mathrm{v})$ denaturing formaldehyde agarose gels according to the method described by Sambrook et al., (1989).

\subsection{Construction of a subtracted library}

Identical amounts of total RNA isolated from each time point $(0,4,7,15$ and 30 days post pathogen treatment) were pooled together. Total RNA isolated from $P$. infestans was mixed with the total RNA from the control plant tissue to create the control RNA population. mRNA was then isolated from each pooled total RNA. Suppression subtractive hybridisation technique was performed using $2 \mu \mathrm{g}$ of control and tester mRNA, according to the Clontech PCR-Select ${ }^{\mathrm{TM}}$ cDNA subtraction protocol based on the original method described by Diatchenko et al., (1996).

Two subtractions were made (i.e. forward and reverse subtractions) and the resulting PCR products of the forward subtraction were cloned into the PCR II vector and transformed into TOPO cells (TOPO TA cloning Kit, invitrogen). The resulting PCR products of the forward and reverse subtraction were used as probes in the differential screening procedure.

\subsection{Screening of differentially expressed clones \\ Randomly selected colonies from the subtraction library were picked and grown in $100 \mu \mathrm{l}$}


of LB-broth medium containing $100 \mu \mathrm{g} / \mathrm{ml}$ ampicillin in a 96-well microplate. A 48 pin metal inoculator was used to transfer aliquots of each bacterial culture onto nylon membranes (Hybond$\mathrm{NX}$; Amersham Biosciences), which were placed onto LB-agar plates containing $100 \mu \mathrm{g} / \mathrm{ml}$ ampicillin. The membrane plates were then incubated at $37^{\circ} \mathrm{C}$ overnight. Several replica membranes were prepared for hybridization with forward and reverse subtracted probes. The labelled probes were synthesized by digoxygenin (DIG)labelling of DNA fragments generated by PCR according to the instructions provided with the PCR DIG Probe synthesis Kit (Roche). The detection of probe-target hybrids was carried out according to the instruction manual supplied with DIG luminescent detection Kit (Roche).

\subsection{Sequence analysis}

The clones that hybridized with the forward subtracted probes but not with the reverse probes were selected for sequencing. The cDNA inserts were sequenced using either the SP6 or T7 promotor primers, flanking the vector's multiple cloning site using the genetic analyzer system 310. DNA sequence comparisons were carried out with those entries in the primary databases, Genbank (at National Centre for Biotechnology Information (NCBI), Maryland, USA) and the TIGR consortium (The Institute for Genomic Research) databases using their corresponding BLAST (Basic Local Alignment Search Tool) search engines at (http://www.ncbi.nlm.nih.gov/blast/Blast.cgi) and (http://compbio.dfci.harvard.edu/tgi/cgi-bin/tgi/ Blast/index.cgi), respectively.

\section{RESULTS AND DISCUSSION}

\subsection{Selection of a virulence $P$. infestans isolate and a resistant potato cultivar}

In order to isolate genes expressed during the resistance interaction between potato and $P$. infestans, a resistant potato cultivar and a virulence isolate of $P$. infestans had to be selected. Ten $P$. infestans isolates were collected from diseased fields in Gharbia, Beheira and Kafr Elshaikh Governorates, Egypt. Two of the ten tested isolates were more virulent (isolates 4 and 6), while the others varied from low to moderate virulent. Isolate 4 - the highest virulent one - was selected for susceptibility test. Six different potato cultivars (Atlantic , Desiree, Goldrush, Nicola, Sante, and Spunta) were tested for their resistance to infection with the highest virulence isolate of $P$. Infestans (Isolate 4). The results indicated that Spunta cv. is considered as the resistant variety; Sante cv. and Nicola cv. were moderately resistant; Desiree cv. and Atlantic cv. were moderately susceptible, while Goldrush cv. was highly susceptible. From these results Spunta cultivar and Isolate 4 of P. Infestans were selected for the construction of the subtracted library.

\subsection{Construction and differential screening of the subtracted cDNA library}

Suppression subtractive hybridisation (SSH) is a PCR-based method that has been developed to enrich rare transcripts and low-abundance genes in animal systems (Diatchenko et al., 1996). SSH is a powerful technique that produces a library of cDNA clones that are differentially expressed between one mRNA-population (tester) compared with a second, control, mRNA-population (driver). The normalisation step equalises the abundance of cDNAs within the target population and the subtraction step excludes the common sequences between the target and driver populations. It was reported that the $\mathrm{SSH}$ technique enriched for rare sequences over 1,000-fold in one round of subtractive hybridisation (Diatchenko et al., 1996). Recently, several applications, using this method, have been reported in plant systems (Beyer et al., 2001; Caturla et al., 2002; Hu et al., 2006; and Kim 2006).

The technique was not only used to subtract the common sequences between the tester (treatedSpunta) and the driver (control-Spunta) populations but also included subtraction of the pathogen sequences, which may have been presented in the treated plant samples, in order to avoid isolating clones carrying gene sequences of fungal origin. This was achieved by mixing the total RNA from cultured $P$. infestans mycelium with the pooled total RNA from the control plant tissues to create the driver RNA population for the forward subtraction. This approach along with the strategy for sampling plant tissue free from pathogen were judged very effective for preventing the isolation of any clone carrying gene sequences of pathogen origin in the subtracted library since no positive hybridization of any library clones with probe prepared from the pathogen.

Beyer et al., (2001) used the same idea to subtract constitutively expressed $P$. infestans sequences from potato plants challenged with 
zoospores of $P$. infestans, while constructing a library to screen for genes induced in potato during the interaction between potato and $P$. infestans using the SSH technique.

After detailed considerations made in the light of our previous findings (Shehab, 2002), it was decided to use the control and treated Spunta tissues samples at various time stages starting from the prechallenged plants "time 0 " through to the establishment of the resistant shoots "30 days" post challenge. This is covering genes up/down regulated during early to late responses.

To generate cDNA subtracted library enriched for gene sequences induced during the compatible interaction, two mRNA populations were prepared: a target sample from a pool of total RNA from potato plants treated with $P$. infestans (tester) and a control from a pool of total RNA from untreated potato plants (driver) (Figure 1). Starting from these samples, forward and reverse subtracted cDNA pools were made. Tester and driver double strandedcDNAs (ds-cDNAs) were prepared from the corresponding mRNA populations. The ds-cDNAs produced from both control and challenged plants were in the size range of about $0.2-2.0 \mathrm{~Kb}$ as estimated by agarose gel electrophoresis and the dscDNAs were subjected to RsaI digestion, separately, to generate short, blunt-ended fragments. Following the PCR-select subtraction procedure, the tester was subtracted twice by the addition of the driver and the differentially expressed sequences were subjected to PCR amplification (Figure 2). The PCR products of the forward subtracted cDNA pool were cloned in a PCRII vector. 380 clones were randomly picked, transferred to microplates for storage and also arrayed in duplicate onto nylon membranes for differential screening with DIGlabelled cDNA probes prepared from forward and reverse subtracted cDNA (Figure 3). Thirty of the 139 clones that hybridized with the forward subtracted probe (i.e. up-regulated gene sequences) were selected for sequencing. The plasmids of these selected clones were isolated and the cDNA inserts were checked by electrophoresis after restriction with $E c o R$ I (data not shown). The inserts varied in size from $190 \mathrm{bp}$ to $596 \mathrm{bp}$.

\subsection{Sequence analysis}

A summary of the homology search results against Genbank and TIGR databases is given in Table 1 . The cDNA inserts of all the selected clones -except three- showed very high similarity (93\% -
$100 \%$ ) with identified nucleotide sequence entries in the databases. Only three sequences $(10 \%)$, clones 13,14 and 26 showed low similarity $(67 \%, 72 \%$ and $60 \%$, respectively) when compared with nucleotide and protein sequence databases, and probably represent new undescribed potato sequences. The rest had significant matches to known genes or EST sequences present in either Gene bank or the TIGR databases at the time of writing the paper.

As expected the sequence search of the selected clones revealed homology to diverse classes of genes, and thus were organized into categories according to their putative function as summarised in (Figure 4). Inevitably in a classification scheme of this design many sequences may contribute to more than one category. One such example was PAL, which could be categorised as a metabolism related sequence or as a stress response related sequence because it plays an important role in the phenylpropanoid metabolic pathways leading to the production of phytoalexins that are shown to be induced under various stress responses (Abenthum et al., 1995; and Hammerschmidt, 1999). In such cases, the most likely biological function for this sequence was chosen. The categories included: (A) defence and stress related sequences, which was the largest category of sequences - as expected - 19 sequences (comprising 63.3\%), including sequences such as chalcone synthase, hydroxymethylglutaryl coenzyme A reductase, superoxide dismutase, proteinase inhibitor (PR-6), and secretory peroxidase (PR-9); (B) signalling-related sequences: 3 sequences (comprising 10\%), such as patatin and ADP-ribosylation factor 1; (C) metabolism related sequences: one sequence (clone 23) comprising $3.3 \%$ and (D) those with unidentified functions: 7 sequences $(23.3 \%)$, clones $24-30$ (Table 1$)$.

These specific categories are very relevant to the potato- $P$. infestans studies. Indeed several of the homologous sequences identified have come from similar biological systems, which were published during the course of this project. Similar results were obtained in different studies of a plantpathogen interaction (Fristensky et al. 1999; Beyer et al. 2001; Rauyaree et al., 2001; Evers et al., 2003; and Wang et al., 2005).

Identification of cDNA's for many genes previously characterised from other species in this system provides corroboration of the involvement and potential importance of these components in 



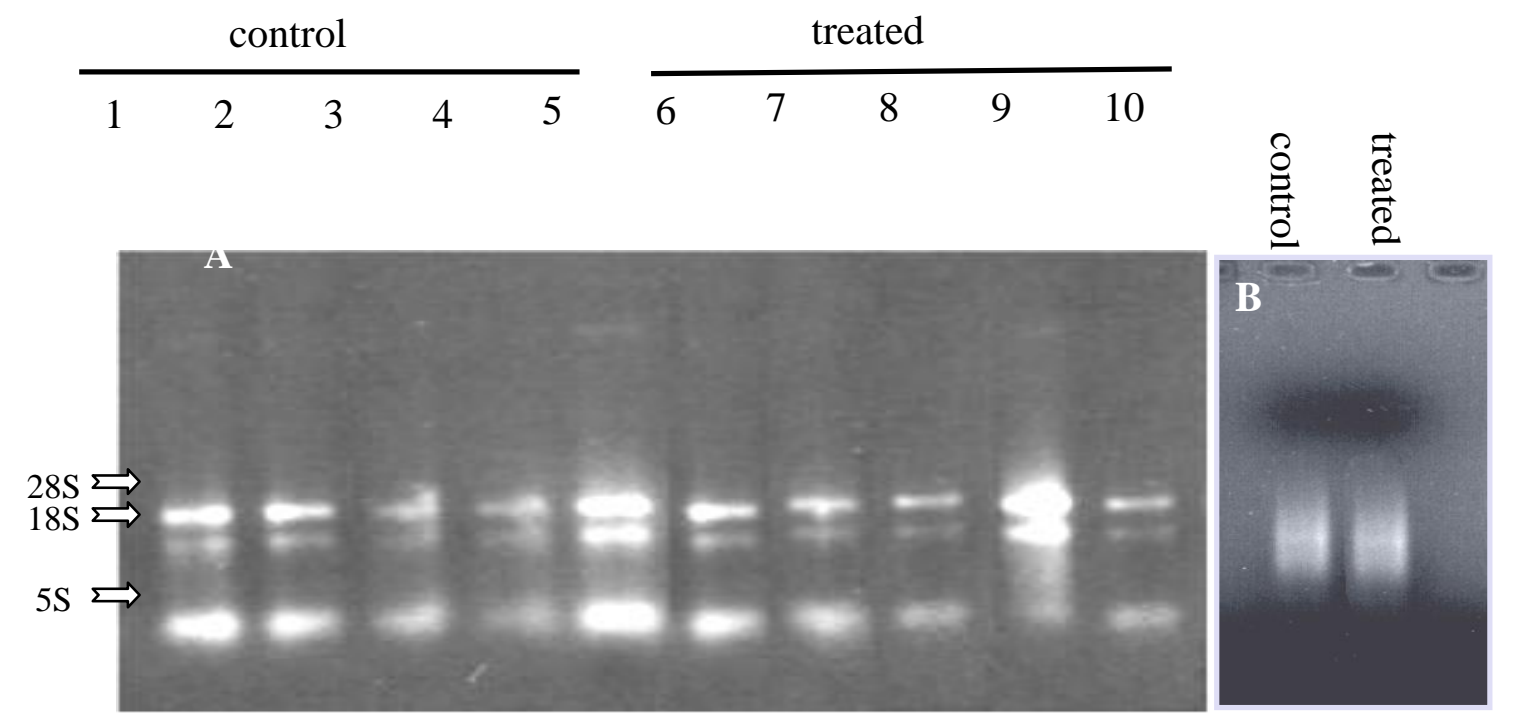

Fig. (1): Electrophoretic analyses of the total and mRNA from Spunta tissues: A) Lanes 1-5 represent the samples from the control plants, while Lanes 6-10 represent the samples from the plants treated with the pathogen; B) mRNA isolation from the pooled total RNA.

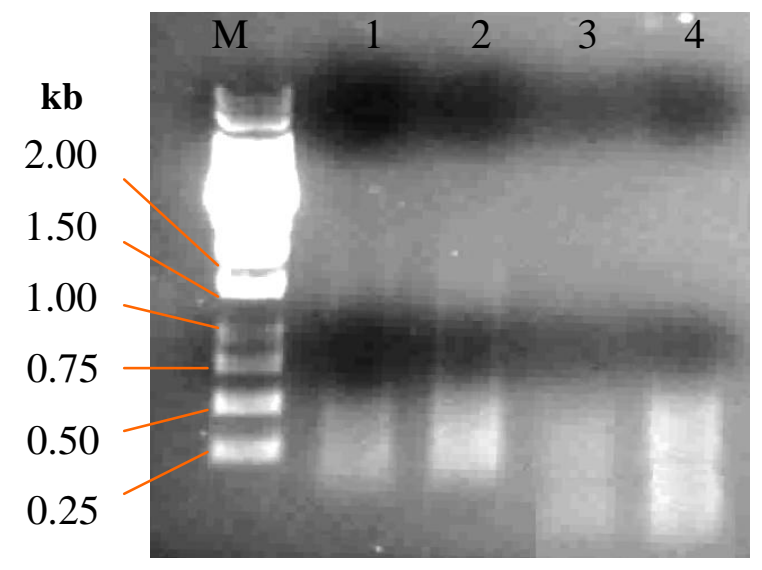

Fig. (2): Electrophoretic analyses of ds cDNA preparations: ds cDNA from the challenged (lane 1) and unchallenged Spunta plants (lane 2), the corresponding Rsal digest from challenged (lane 3) and unchallenged Spunta plants (lane 4). $M$ = size marker-GeneRuler 1kb DNA ladder.
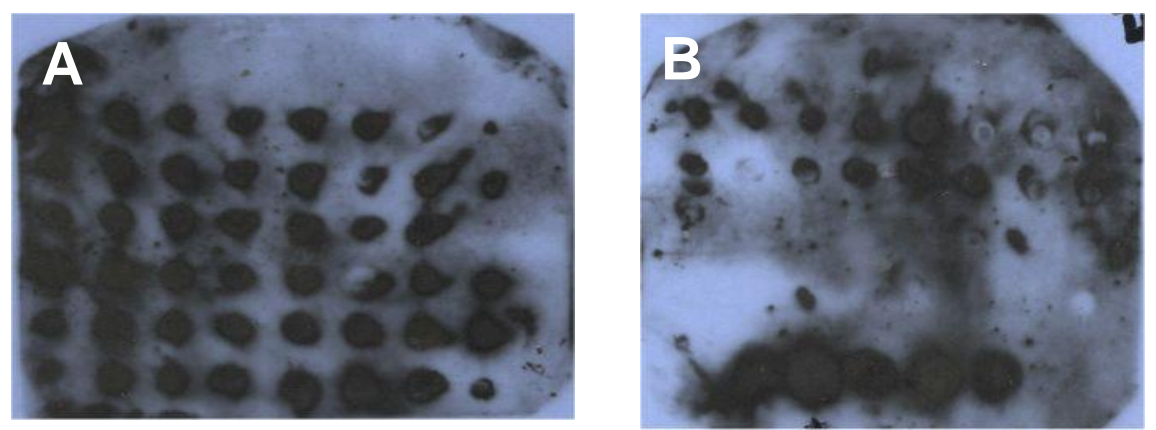

Fig.(3): Screening the subtracted library for differentially expressed cDNA sequences. The X-ray film of the membranes after hybridization with forward subtracted cDNA probe (A) and reverse subtracted CDNA probe (B). Black spots on membrane $A$ but not on membrane $B$ indicate differentially expressed clones; while black spots on both membranes indicate clones that considered as representing sequences that are .... d:se.......:-11.. .............

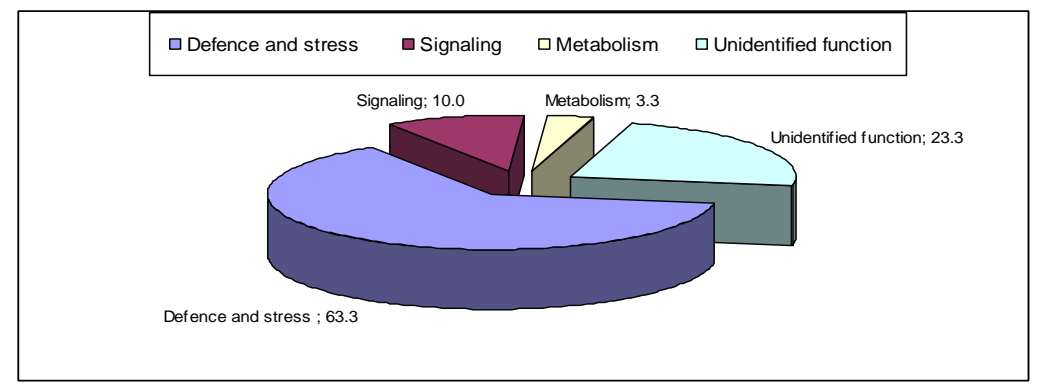


Table (1): Summary of the homology search results.

\begin{tabular}{|c|c|c|c|c|c|c|c|c|}
\hline Clone & $\begin{array}{c}\text { Length } \\
\text { (bp) }\end{array}$ & Sequence homologue & Species & Identities & $\mathbf{A C}^{*}$ & Database & Putative function & Notes \\
\hline 1 & 485 & Chalcone synthase & Potato & $484 / 484(100 \%)$ & STU47740 & NCBI & $\begin{array}{c}\text { Catalyze the first step in } \\
\text { flavonoid biosynthesis } \\
\text { pathway }\end{array}$ & \\
\hline 2 & 298 & Auxin-repressed protein & Potato & $298 / 298(100 \%)$ & TC160468 & TIGR & Stress response & \\
\hline 3 & 293 & $\begin{array}{l}\text { Hydroxymethylglutaryl } \\
\text { coenzyme A reductase }\end{array}$ & Potato & $245 / 245(100 \%)$ & L01401.1 & NCBI & $\begin{array}{c}\text { Catalyze the rate-limiting step } \\
\text { in terpinoid phytoalexin } \\
\text { production }\end{array}$ & \\
\hline 4 & 596 & Glutathione-S-transferase & Potato & $591 / 596(99 \%)$ & TC137208 & TIGR & $\begin{array}{c}\text { Detoxification and Stress } \\
\text { response }\end{array}$ & \\
\hline 5 & 296 & Superoxide dismutase & Potato & $296 / 297(99 \%)$ & AF355460.1 & NCBI & Oxidative stress & \\
\hline 6 & 137 & Ci21A protein & Potato & $136 / 138(98 \%)$ & TC142298 & TIGR & Stress response & \\
\hline 7 & 546 & Protein At1g70830 & Potato & $513 / 548(93 \%)$ & TC144354 & TIGR & Stress response & \\
\hline 8 & 566 & Phenylalanine ammonia-lyase & Potato & $565 / 566(99 \%)$ & X63103.1 & NCBI & \begin{tabular}{|c|} 
Catalyzes the first step in the \\
biosynthesis of \\
phenylpropanoids
\end{tabular} & \\
\hline 9 & 339 & Secretory peroxidase & Tobacco & $336 / 336(100 \%)$ & AB178954.1 & NCBI & $\begin{array}{c}\text { Stress response } \\
(\text { PR-9) }\end{array}$ & Novel \\
\hline 10 & 261 & Aspartic proteinase inhibitor & Potato & $261 / 262(99 \%)$ & STU30814 & NCBI & Pathogenesis-related protein & PR-6 \\
\hline 11 & 315 & $\mathbf{P 2 3}$ protein & Potato & $303 / 315(96 \%)$ & Z37160.1 & NCBI & Pathogenesis-related protein & PR-5 \\
\hline 12 & 258 & $\begin{array}{c}\text { Wound-induced protein WIN2 } \\
\text { precursor }\end{array}$ & Potato & $258 / 258(100 \%)$ & P09762 & NCBI & Stress response & \\
\hline 13 & 380 & PR-protein Q & Tobacco & $106 / 156(67 \%)$ & AB286841 & NCBI & Pathogenesis-related protein & Novel \\
\hline 14 & 503 & $\begin{array}{c}\text { Avr9/Cf-9 rapidly elicited } \\
\text { protein } 65\end{array}$ & Potato & $115 / 158(72 \%)$ & TC146042 & TIGR & Pathogenesis-related protein & \\
\hline 15 & 290 & $\begin{array}{c}\text { EST497292 } P . \text { infestans- } \\
\text { challenged leaf }\end{array}$ & Tomato & $261 / 263(98 \%)$ & BG589450 & NCBI & Stress response & Novel \\
\hline 16 & 503 & EST286026 mixed elicitor & Tomato & $299 / 312(95 \%)$ & AW092846 & NCBI & Stress response & Novel \\
\hline 17 & 309 & $\begin{array}{c}\text { EST654322 } P \text {. infestans- } \\
\text { challenged cell suspension } \\
\text { culture }\end{array}$ & Potato & $308 / 313(99 \%)$ & TC27621 & TIGR & $\begin{array}{c}\text { Protein turnover and stress } \\
\text { response }\end{array}$ & \\
\hline 18 & 396 & $\begin{array}{c}\text { EST536915 } P . \text { infestans- } \\
\text { challenged leaf }\end{array}$ & Tomato & $145 / 150(96 \%)$ & BI434154 & NCBI & Stress response & Novel \\
\hline 19 & 203 & Ubiquitin conjugating protein & Potato & 201/203 (99\%) & TC27621 & TIGR & & \\
\hline 20 & 326 & Patatin-like protein & Potato & $293 / 300(97 \%)$ & TC18191 & TIGR & & \\
\hline 21 & 190 & Patatin & Potato & $189 / 190(99 \%)$ & Z27221.1 & NCBI & & \\
\hline 22 & 368 & ADP-ribosylation factor 1 & Potato & $352 / 368(95 \%)$ & X74461.1 & NCBI & $\begin{array}{c}\text { Cellular regulator for } \\
\text { phospholipase D (PLD) }\end{array}$ & \\
\hline 23 & 253 & $\begin{array}{c}\text { Myo-inositol-1-phosphate } \\
\text { synthase }\end{array}$ & Potato & $253 / 253(100 \%)$ & TC112573 & TIGR & & \\
\hline 24 & 275 & $\begin{array}{c}\text { Unknown (IQ calmodulin- } \\
\text { binding motif, PF02179 ) }\end{array}$ & Potato & $275 / 275(100 \%)$ & TC119109 & TIGR & & \\
\hline 25 & 474 & $\begin{array}{l}\text { Unknown function (Dehydrin- } \\
\text { like protein) }\end{array}$ & Potato & $139 / 140(99 \%)$ & AF542504.1 & NCBI & & \\
\hline 26 & 204 & $\begin{array}{c}\text { Putative glucosyl transferase } \\
\text { (Arabidopsis thaliana) }\end{array}$ & Tomato & $111 / 185(60 \%)$ & AW944800 & NCBI & & Novel \\
\hline 27 & 364 & $\begin{array}{c}\text { Hypothetical protein (rubber } \\
\text { elongation factor protein } \\
\text { (REF), ) }\end{array}$ & Potato & $263 / 264(99 \%)$ & TC27841 & TIGR & & \\
\hline 28 & 258 & Unknown protein & Arabidobsis & $245 / 253(97 \%)$ & AY086126 & NCBI & & Novel \\
\hline 29 & 412 & Unknown protein & Arabidobsis & $402 / 412(98 \%)$ & NM_105999 & NCBI & & Novel \\
\hline 30 & 377 & Unknown protein & Oryza sativa & $303 / 207(99 \%)$ & BAD16841 & NCBI & & Novel \\
\hline
\end{tabular}

$* \mathrm{AC}=$ accession number. 
similar plant-pathogen situations. While the identification of such cDNA's is important, the value of the 'unknown class' of cDNA's, comprising a significant $23.3 \%$ of the subtraction cDNA's plus 4 clones (15-18) (13.3\%) categorised with the stress- and defence-related sequences. They have homology to ESTs isolated from pathogen or elicitor treated leaves or cell cultures, and showed strong homology to sequences in the databases of unknown function, should not be underestimated. Results on the expression profile of these genes during the compatible interaction between potato and $P$. infestans may shed light on their potential defence function. These genes are also only a subset from the total library of more than 380 clones, of which 139 clones were hybridized with the forward probe but not with the reverse probe. This means more than 109 clones still to be evaluated.

Interestingly, among the thirty sequenced cDNA's, nine $(30 \%)$ were novel potato gene sequences (Table 1). These sequences will eventually be submitted to the DNA databases. The level of the redundancy in the selected clones was calculated. Among the thirty sequences, two ( $7 \%)$ were found twice. These two sequences were homologous to patatin and patatin-like protein. Patatin is identical to cytosolic phospholipase A2, which involves in signal transduction. The abundance of these sequences ( $7 \%$ ) compared with others may reflect their importance in establishing the potato resistance response.

More clones should be sequenced and analyzed in order to accomplish a clear idea about the genes involved in the resistance to late blight disease. Moreover, the expression of these genes should be studied in order to know which one is expressed early and which one is expressed late in the battle between the pathogen and the plant.

\section{Acknowledgments}

This work was financially supported by Cairo University (Projects for young researchers). We thank Dr Abdel-Kader Abdel-Samad for his support and advice during this project.

\section{REFERENCES}

Abenthum K., Hildenbrand S. and Ninnemann H. (1995). Elicitation and accumulation of phytoalexins in stems, stolons and roots of Erwinia-infected potato plants. Physiological and Molecular Plant Pathology 46, 349-359.
Avrova A.O., Stewart H.E., De Jong W., Heilbronn J., Lyon G.D. and Birch P.R. J. (1999). A cysteine protease gene is expressed early in resistant potato interactions with Phytophthora infestans. Molecular PlantMicrobe Interactions 12, 1114-1119.

Beyer K., Binder A., Boller T. and Collinge M. (2001). Identification of potato genes induced during colonization by Phytophthora infestans. Molecular Plant Pathology 2, 125-134.

Birch P.R.J., Avrova A.O., Duncan J.M., Lyon, G.D. and Toth R.L. (1999). Isolation of potato genes that are induced during an early stage of the hypersensitive response to Phytophthora infestans. Molecular Plant-Microbe Interactions 12, 356-361.

Caturla M., Chaparro C., Schroeyers K. and Holsters M. (2002). Suppression subtractive hybridization to enrich low-abundance and submergence-enhanced transcripts of adventitious root primordia of Sesbania rostrata. Plant Science 162, 915-921.

Chomczynski P. and Sacchi N. (1987). Single-step method of RNA isolation by acid guanidium thiocyanate-phenol-chloroform extraction. Analytical Biochemistry 162, 156-159.

Colon L.T., Turkensteen L. J., Prummel Budding W. D.J. and Hoogendoorn J. (1995). Durable resistance to late blight (Phytophthora infestans) in old potato cultivars. European Journal of Plant Pathology 101, 387-397.

Diatchenko L., Lau Y.F.C., Campbell A.P., Chenchik A., Moqadam F., Huang B., Lukyanov S., Lukyanov K., Gurskaya N., Sverdlov E.D. and Siebert P.D. (1996). Suppression subtractive hybridization: A method for generating differentially regulated or tissue-specific cDNA probes and libraries. Proceedings of the National Academy of Sciences of the United States of America 93, 6025-6030.

Duncan J.M. (1999). Phytophthora-an abiding threat to our crops. Microbiology Today 26, 114-116.

Evers D., Ghislain M., Hausman J. and Dommes J. (2003). Differential gene expression in two potato lines differing in their resistance to Phytophthora infestans. Journal of Plant Physiology 160, 709 - 712.

Ewing E.E., Simko I., Smart C.D., Bonierbale M.W., Mizubuti E.S.G., May G.D. and Fry W.E. (2000). Genetic mapping from field tests 
of qualitative and quantitative resistance to Phytophthora infestans in a population derived from Solanum tuberosum and Solanum berthaultii. Molecular Breeding 6, 25-36.

Fristensky B., Balcerzak M., He D. and Zhang P. (1999). Expressed sequence tags from the defense response of Brassica napus to Leptosphaeria maculans. Molecular Plant Pathology On-line.

(http://www.bspp.org.uk/mppol/1999/0301 FRISTENSKY).

Fry W.E. and Goodwin S.B. (1997). Resurgence of the Irish potato famine fungus. Bioscience 47, 363-371.

Gebhardt C. and Valkonen J.P.T. (2001). Organization of genes controlling disease resistance in the potato genome. Annual Review of Phytopathology 39, 79-102.

Hammerschmidt R. (1999). Phytoalexins: what have we learned after 60 years? Annual Review of Phytopathol. 37, 285-306.

Hu H., Zhuang J., Chai R., Wu J., Fan Y. and Zheng K. (2006). Isolation and Characterization of Defense Response Genes Involved in Neck Blast Resistance of Rice. Acta Genetica Sinica 33 (3), $251-261$.

Kim J. and Kim H. (2006). Functional analysis of a calcium-binding transcription factor involved in plant salt stress signaling. FEBS Letters 580(22), 5251-5256.

Rauyaree P., Choi W., Fang W., Blackmon B. and Dean R.A. (2001). Genes expressed during early stages of rice infection with the rice blast fungus
Magnaporthe grisea. Molecular Plant Pathology 2, 347-354.

Sambrook J.M., Fritsch E. F. and Maniatis T. (1989). Molecular cloning: A Laboratory Manual. Cold Spring Harbor Laboratory Press: Cold Spring Harbor, NY.

Shehab G.M.G. (2002). Molecular Aspects of Resistance to Late Blight Disease in Potato (Solanum tuberosum L). Ph. D. Thesis University of Durham. UK.

Vleeshouwers V. G. A. A., van Dooijeweert W., Govers F., Kamoun S. and Colon L.T. (2000). Does basal PR gene expression in Solanum species contribute to non-specific resistance to Phytophthora infestans?. Physiological and Molecular Plant Pathology 57, 35-42.

Wang B., Liu J., Tian Z., Song B. and Xie C. (2005). Monitoring the expression patterns of potato genes associated with quantitative resistance to late blight during Phytophthora infestans infection using cDNA microarrays. Plant Science 169, 1155-1167.

Wang X., El Hadrami A., Adam L. R. and Daayf F. (2005). Genes encoding pathogenesis-related proteins PR-2, PR-3 and PR-9, are differentially regulated in potato leaves inoculated with isolates from US-1 and US-8 genotypes of Phytophthora infestans (Mont.) de Bary. Physiological and Molecular Plant Pathology 67, 49-56.

Zhu B., Chen T.H. and Li P.H. (1995). Expression of three osmotin-like protein genes in response to osmotic stress and fungal infection in potato. Plant Molecular Biology 28, 17-26. 


\section{دراسات جزيئية لفهم أسس مقاومة نبات البطاطس للإصابة بفظر Phytophthora infestans}

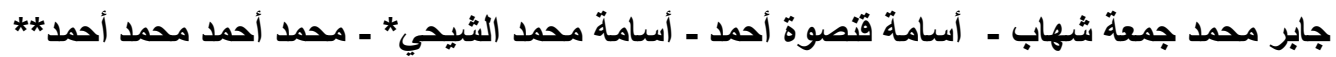

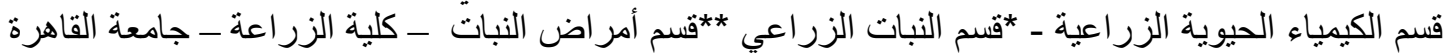

\section{ملخص}

يعتبر فطر Phytophthora infestans من أثد الميكروبات ضراوةً وتأثثراً على محصول البطاطس فى جميع أنحاء العالم مسبباً لمرض الندوة المتأخرة فى البطاطس.

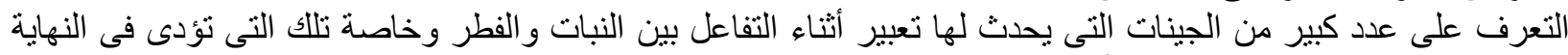

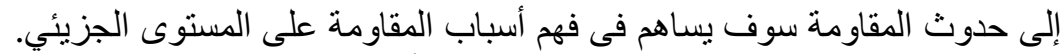

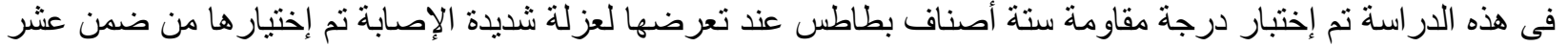
عز لات و التى كانت قد عزلت من حقول بطاطس مصابة فى محافظات الغربية و البحيرة وكفر التئية الثيخ.

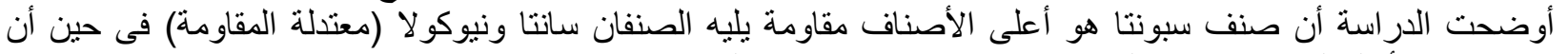

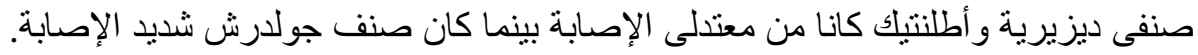

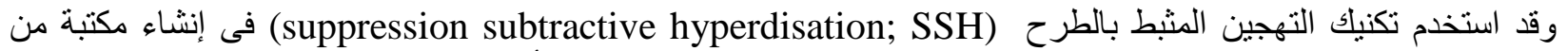

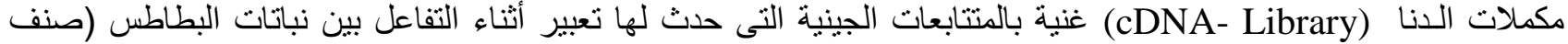

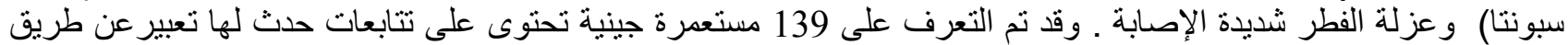

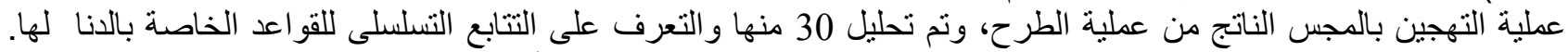

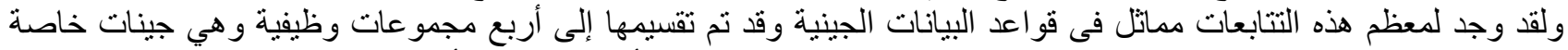

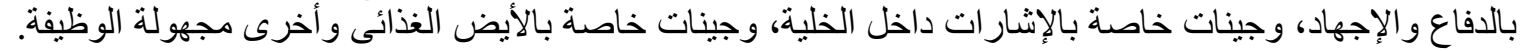

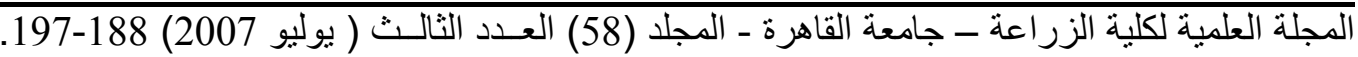

